\title{
PERAN SISTEM IMUN TERHADAP TERJADINYA PNEUMONIA TERKAIT STROKE
}

\author{
THE ROLE OF IMMUNE SYSTEM ON THE OCCURRENCE OF STROKE- \\ ASSOCIATED PNEUMONIA
}

Al Rasyid*

\section{ABSTRACT}

Stroke associated pneumonia (SAP) is one of the medical complication which associated with high mortality rate. Several studies conclude two factors involve significantly in pathophysiology of SAP, one of which is immunodepression state. Immunodepression occurs by 3 main pathways, symphathetic system activation, parasymphathetic system activation, and HPA (hypothalamus-pituitary-adrenal) axis activation. Simultaneously, they induce proinflammatory response suppression and immune cells alternation, which lead to an infection like pneumonia. Therefore, establishing an effective immunomodulation therapy could be one of the main focus in comprehensive stroke management's future studies.

Keywords: Immunodepression, stroke-associated pneumonia

\section{ABSTRAK}

Komplikasi pneumonia terkait stroke menjadi salah satu faktor penyebab mortalitas tertinggi. Studi-studi menyimpulkan bahwa ada dua faktor yang berperan pada patofisiologi pneumonia, salah satunya adalah imunodepresi terkait stroke. Imunodepresi terjadi melalui 3 jaras, yaitu aktivitas simpatis, aktivitas parasimpatis, dan aksis hipotalamuspituitari-adrenal. Secara simultan, ketiganya menekan respons proinflamasi dan mengubah sel-sel imun sehingga pneumonia dapat mudah terjadi. Pembuatan terapi imunomodulasi yang dapat mencegah infeksi namun tidak memperburuk kondisi iskemia dapat menjadi fokus studi penanganan stroke komprehensif di masa datang.

Kata kunci: Imunodepresi, pneumonia terkait stroke

*Divisi Neurovaskular Departemen Neurologi FK Universitas Indonesia/RSUPN Dr. Cipto Mangunkusumo, Jakarta. Korespodensi: alrasyid50@yahoo.com.

\section{PENDAHULUAN}

Stroke menjadi penyebab utama kematian dan kecacatan tertinggi di dunia. Salah satu penyebabnya adalah terjadinya berbagai komplikasi medis dan neurologis pascaserangan stroke seperti pneumonia. Pneumonia terjadi pada $10 \%$ pasien stroke yang mendapat perawatan di rumah sakit, terutama pada 3 hari pascaserangan stroke. ${ }^{1}$ Bahkan, di beberapa studi, insiden pneumonia terkait stroke/stroke-associated pneumonia (SAP) mencapai 40\%. ${ }^{1}$ Pneumonia menjadi penyebab $35 \%$ kematian dalam rentang waktu 30 hari sejak awitan stroke. Angka kematian pasien stroke dengan pneumonia ternyata tiga kali lebih tinggi dibandingkan tanpa komplikasi pneumonia. ${ }^{2}$ Selain meningkatkan angka mortalitas, pneumonia turut menyebabkan peningkatan biaya perawatan, lama rawat, serta luaran lebih buruk pada penyintas stroke. ${ }^{1}$ Terlebih, belum tersedianya terapi yang efektif dalam melawan infeksi yang terjadi mendorong pemahaman komprehensif terhadap komplikasi ini.

Berbagai teori telah diuji untuk mengetahui patofisiologi pneumonia terkait stroke. Teori yang telah lama dipercaya di kalangan klinisi ialah pneumonia timbul setelah terjadinya aspirasi sekret mulut atau sisa makanan, sebuah fenomena yang umum terjadi karena pasien mengalami disfagia pascastroke/poststroke dysphagia (PSD). ${ }^{3}$ Tidak mengherankan bila risiko pneumonia pada pasien dengan PSD meningkat signifikan, yaitu berkisar tiga hingga sebelas kali lipat dibandingkan pasien tanpa gejala disfagia. ${ }^{4}$ Namun, disfagia maupun aspirasi tidak dapat menjelaskan insiden SAP yang tinggi. Terlebih, aspirasi dapat pula terjadi pada individu sehat tanpa mengakibatkan pneumonia. ${ }^{5}$ Paradigma terbaru menyimpulkan adanya peran sistem imun berupa overaktivitas simpatis dan jaras hipotalamus-hipofisis-adrenal. ${ }^{5}$ Kondisi imunodepresi yang terjadi dipercaya memiliki peran kunci dalam infeksi bakteri yang terjadi. Oleh karena itu, pemahaman yang lebih baik terhadap patofisiologi pada otak dan perifer pascastroke dapat mendorong pengembangan terapi untuk menurunkan mortalitas dan morbiditas serta memperbaiki luaran klinis.

Tulisan ini akan membahas pneumonia terkait stroke, terutama aspek imunologi mekanisme 
pneumonia terkait stroke dan modalitas terapi yang dapat dipertimbangkan. Diharapkan, klinisi menyadari potensi intervensi yang menyasar sistem imun dalam melawan komplikasi infeksi pascastroke.

\section{PEMBAHASAN}

\section{Definisi dan Insiden Pneumonia Terkait Stroke}

Pneumonia pascastroke, atau pneumonia terkait stroke/SAP, adalah pneumonia yang timbul minimal setelah 72 jam pascaperawatan di rumah sakit pada pasien pascaserangan stroke. ${ }^{6}$ Selanjutnya, studi Teramoto dkk, membagi pneumonia pascastroke berdasarkan waktu, yaitu akut (timbul dalam 1 bulan setelah awitan stroke) dan kronik ( $>1$ bulan setelah awitan stroke). ${ }^{7}$ Umumnya, berbagai studi memakai kriteria center of disease control and prevention (CDC) terkait definisi pneumonia nosokomial ini. Melalui kriteria CDC, healthcare pneumonia dibagi menjadi 3, yaitu pneumonia yang terbukti klinis, pneumonia dengan patogen umum, serta pneumonia pada pasien imunokompromi. ${ }^{8}$

Menurut studi Hannawi dkk, pasien yang dirawat di neurological intensive care unit (NICU) memiliki insiden pneumonia pascaaspirasi berkisar antara 4,1-56,6\% sedangkan di unit stroke sebesar 3,9-44\%. ${ }^{9}$ Walau sulit dilakukan perbandingan karena studi-studi yang dilakukan bersifat heterogen, namun satu hal yang dapat disimpulkan adalah insiden pneumonia pascastroke lebih tinggi pada ruang intensif, seperti NICU, dibandingkan di unit stroke atau ruang rawat akut. Hal ini dibuktikan oleh metaanalisis Westendorp WF dkk, di tahun 2011. ${ }^{10}$ Beberapa hal yang mendasari hal ini antara lain efek komorbid penyakit yang lebih berat, efek pemasangan ventilasi mekanik, maupun derajat stroke yang umumnya lebih berat pada pasien di unit perawatan kritis.

\section{Patofisiologi Pneumonia Terkait Stroke}

Pneumonia terkait stroke, secara patofisiologi, terjadi akibat 2 faktor yang terjadi secara simultan, yaitu aspirasi dan imunodepresi terkait stroke melalui serangkaian jaras humoral dan neural. Pada bagian ini, akan dibahas mendalam terkait dua faktor tersebut.

\section{Teori Aspirasi Klasik}

Sejak lama, SAP dipandang sebagai fenomena yang terjadi setelah aspirasi dan penurunan fungsi menelan (disfagia). Disfagia maupun aspirasi yang terjadi berkaitan dengan hal-hal yang umum dijumpai pada pasien stroke, seperti menurunnya tingkat kesadaran, pemakaian ventilator, posisi tubuh tertentu yang meningkatkan risiko aspirasi, dan imobilisasi dalam jangka waktu lama. ${ }^{11}$ Namun, disparitas kasus pneumonia antara populasi pasien stroke dibandingkan populasi pasien dengan disfagia saja mengundang tanda tanya besar.

Beberapa studi mencoba menganalisis hal tersebut dari aspek biomolekuler. Menurut studi Arai dkk, gangguan fungsi menelan pada pasien stroke berkaitan dengan transmisi neurotransmiter dopamin yang inadekuat. ${ }^{12}$ Sebuah uji eksperimental membuktikan bahwa blokade reseptor dopamine $\mathrm{D}_{1}$ menyebabkan penghambatan refleks menelan dan penurunan sekresi substansi $\mathrm{P}$ oleh nervus glosofaringeal pada organ-organ tubuh. ${ }^{13}$ Studi lain menyatakan bahwa sputum pasien yang mengalami pneumonia aspirasi memiliki kadar substansi $\mathrm{P}$ yang rendah, sementara itu pasien pascastroke yang telah mengalami resolusi aspirasi memiliki kadar substansi $\mathrm{P}$ serum yang meningkat. ${ }^{12,14}$ Teori lain menyatakan bahwa pada pasien stroke, ditemukan adanya perubahan flora normal di mulut sehingga meningkatkan risiko pneumonia. Beberapa spesies bakteri gram negatif ditemukan pada sputum pasien pascastroke, antara lain Klebsiella pneumoniae, Escherichia coli, Enterobacter cloacae, dan Pseudomonas aeruginosa. ${ }^{15}$

Walau demikian, teori ini belum mampu sepenuhnya menjawab pertanyaan mengapa insiden pneumonia pada populasi yang mengalami stroke lebih tinggi dibanding pasien yang mengalami disfagia maupun penurunan kesadaran saja. Terlebih, frekuensi aspirasi pada individu sehat tidak jauh berbeda dengan pasien stroke. ${ }^{5}$

\section{Teori Imunodepresi}

Stroke, khususnya tipe iskemik, menyebabkan insufiensi aliran darah ke jaringan otak. Ketika aliran darah mengalami stagnasi, sel-sel otak yang 
sangat aktif mengalami kekurangan dua hal untuk kelangsungan hidupnya: nutrien dan oksigen. Tentu saja, bila hal ini terjadi dalam jangka waktu tertentu berakibat pada apoptosis (kematian sel) dan kerusakan jaringan. Kedua hal ini selanjutnya mengaktivasi respons inflamasi pada jaringan otak via berbagai signaling pathway, salah satunya via damage-associated molecular patterns (DAMP). Rangkaian respons inflamasi ini mengakibatkan beberapa perubahan di tingkat jaringan, misalnya ekspresi molekul adhesi berlebihan dan peningkatan sawar darah otak. Inflamasi lokal dan difus hebat ini dapat memicu reaksi kontraregulasi oleh tubuh untuk mencegah kerusakan lebih lanjut, respons inflamasi awal maupun reaksi autoimun yang berpotensi terjadi. Mekanisme ini disebut sebagai imunodepresi pascastroke. ${ }^{11}$ Studi-studi lanjutan menyimpulkan bahwa kondisi imunodepresi ini terjadi melalui 3 cara, yaitu aktivasi sistem simpatis, aktivasi sistem parasimpatis, dan aktivasi jaras hipotalamushipofisis-adrenal. ${ }^{16-17}$ Dampaknya, terjadi pelemahan sistem imun, seperti apoptosis limfosit, pergesaran (shifting) sel T-helper (Th)-1 ke Th2, bakteremia spontan, dan infeksi pascaserangan stroke. ${ }^{18}$ Kondisi ini dikenal dengan istilah imunodepresi terkait stroke (stroke-induced immunodepression). Hal ini akan dibahas lebih mendalam pada pembahasan selanjutnya.
Saat kondisi iskemia, sel otak yang telah rusak memicu respons imun adaptif. Respons ini selanjutnya membentuk suatu reaksi autoimun dalam sirkulasi sistem saraf pusat. Reaksi autoimun yang tidak terkontrol tidak hanya merusak debris dan sel yang telah mati, namun juga menyerang selsel yang sehat. Oleh karena itu, tubuh membentuk kondisi imunodepresi untuk mencegah kerusakan lebih lanjut jaringan otak pascaiskemik. ${ }^{19}$ Melalui aktivitas lokal sitokin-sitokin proinflamatorik, saraf pusat merangsang terjadinya respons antiinflamasi sebagai mekanisme counter-regulatory sehingga tercipta keadaan homeostasis. Sistem imun yang telah dilemahkan meningkatkan kerentanan terhadap infeksi, baik dari flora normal atau bakteri asing. ${ }^{20}$ Salah satu manifestasi infeksi yang umum terjadi adalah pneumonia.

Secara sederhana, patofisiologi SAP yang melibatkan kedua teori diatas terangkum dalam Gambar 1.

\section{Stroke-induced Immunodepression}

Sistem saraf dan sistem imun berhubungan satu sama lain untuk mempertahankan kondisi homeostasis. ${ }^{21}$ Pada cedera otak berat, seperti stroke, keseimbangan di antara keduanya menjadi terganggu. Jejas seluler menyebabkan infiltrasi sel-sel inflamasi

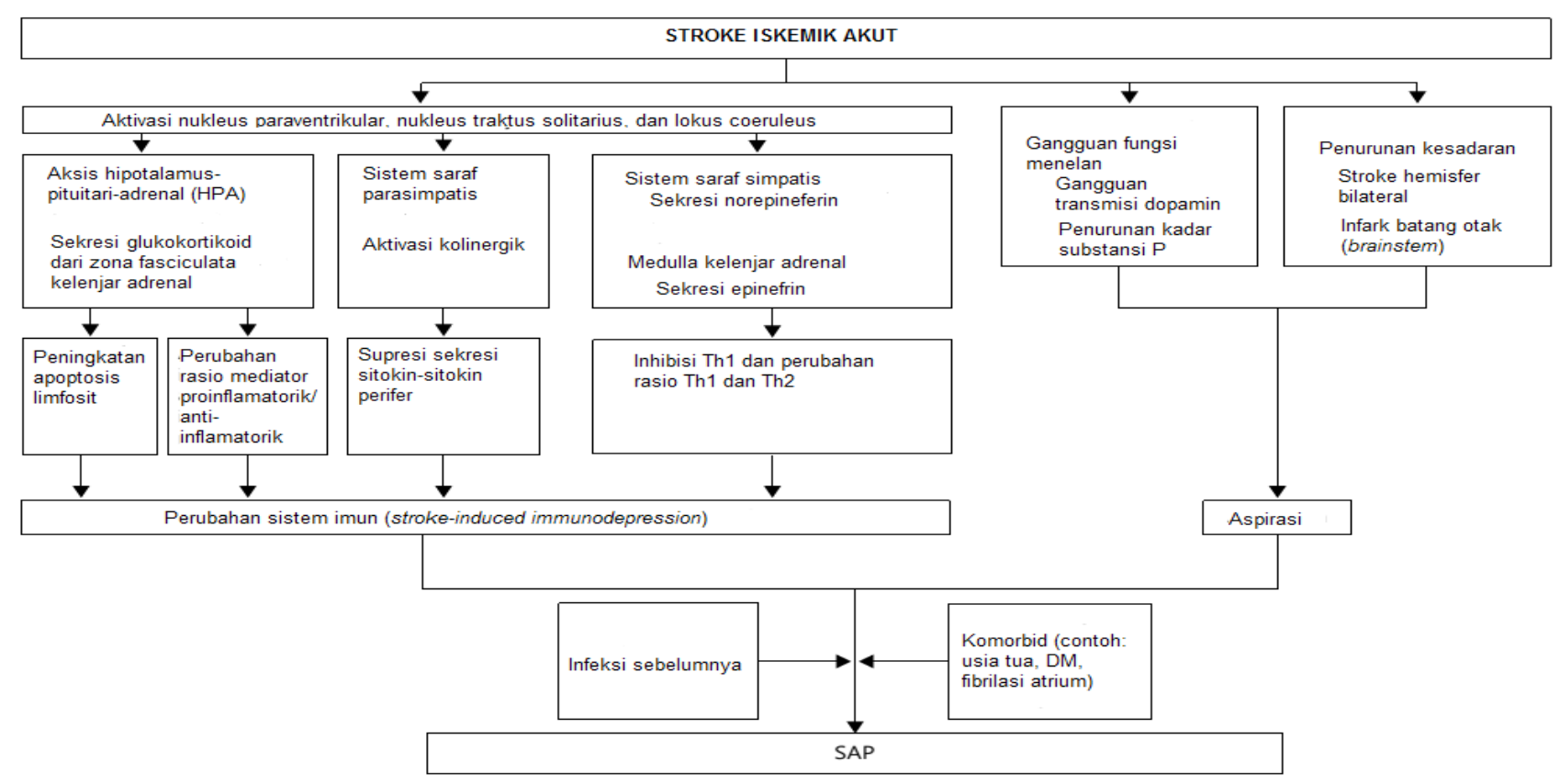

Gambar 1. Patofisiologi Stroke Associated Pneumonia9 
ke dalam jaringan otak, untuk membuang debris serta memulai perbaikan jaringan. Namun, di sisi lain, inflamasi dapat mendorong perluasan lesi stroke dan memperburuk defisit neurologis yang sudah ada. Dengan kata lain, apabila dilakukan inhibisi respons imun pada fase akut stroke, maka meluasnya jejas (injury) pada otak dapat dicegah. ${ }^{21}$

Cedera pada otak dapat mengubah derajat fungsional sistem imun, dari semula bersifat imunokompeten menjadi imunodepresi sebagai mekanisme kontraregulasi. Menurut beberapa teori, stroke-induced immunodepression merupakan bagian dari respons adaptif terhadap cedera otak, sehingga proses inflamasi di otak terhambat serta reaksi autoimun dengan neuroantigen dapat diminimalisasi. ${ }^{17,22}$ Beberapa perubahan yang dapat ditemui pada fase akut antara lain dengan limfopenia, penurunan kadar sitokin proinflamatorik, disfungsi monosit dan limfosit, serta atrofi pada beberapa organ-organ limfoid. ${ }^{21}$

Beberapa studi telah mempelajari fenomena respons imun di tingkat selular stroke iskemik. Sel T sebagai komponen utama imunitas seluler mengalami down-regulation melalui berbagai cara. Studi Heusler $\mathrm{dkk}$, memperlihatkan adanya gangguan respons sel $\mathrm{T}$ dan penurunan kadar limfosit di perifer. ${ }^{23}$ Studi lain menyimpulkan ekspresi major histocompability complexes (MHC) kelas II atau human leucocyte antigen-DR (HLA-DR), molekul yang berperan dalam mempresentasikan antigen ke sel $\mathrm{T}$, turut mengalami penurunan. ${ }^{24}$ Selanjutnya, ditemukan pergantian (shifting) respons sel $\mathrm{T}$, dimana respons T-helper1 (Th1) proinflamatorik berubah menjadi respons T-helper2 (Th2) antiinflamatorik. ${ }^{25}$ Selain mengalami gangguan fungsi, produksi sel $\mathrm{T}$ pun ikut berkurang akibat kematian splenosit dan penurunan produksi faktor mitogenik sel T. ${ }^{18}$ Diperkirakan, inhibisi respons imun seluler merupakan salah satu mekanisme proteksi jaringan otak dari kerusakan oleh inflamasi, serta mendorong regenerasi neuronal. ${ }^{25}$

Di samping perubahan yang ditemukan pada sel $\mathrm{T}$, bukti kondisi imunodepresi terlihat pada respons inflamasi yang terjadi. Respons proinflamasi akan berbalik arah, membentuk respons anti- inflamasi. Hal ini ditandai dengan sekresi IL-10 (interleukin-10), salah satu sitokin antiinflamatorik utama, dalam jumlah yang signifikan dari monosit, sel dendritik, dan sel T regulator. ${ }^{11}$ Sitokin ini berperan dalam menetralisasi respons inflamasi yang telah terjadi serta menghambat produksi berbagai sitokin proinflamatorik, seperti interferon-- $\gamma$ (IFN- $\gamma)$ dan tumor necrosis factor- $\alpha$ (TNF- $\alpha$ ). Implikasi klinis perubahan ini terlihat pada studi Wang dkk, dimana pasien yang mengalami stroke-associated infection (SAI), kadar IL-6 dan IL-10 mengalami peningkatan signifikan, sedangkan ekspresi HLA-DR mengalami penurunan. ${ }^{26}$

\section{Peran Jalur Humoral dan Neural dalam Perubahan Respons Imun}

Mekanisme kontra regulasi berupa imunodepresi adalah hasil kerja jalur humoral dan neural secara simultan. Ketiganya mampu memengaruhi sistem imun dengan perantara sarafsaraf otonom maupun sirkulasi perifer.

Overaktivitas ujung saraf adrenergik dalam sistem saraf simpatis, dianggap menjadi salah satu pilar utama terjadinya imunosupresi pascastroke. Aktivasi saraf simpatis menyebabkan sekresi katekolamin dari medulla adrenal maupun terminal neuron di organ-organ perifer. $^{27}$ Katekolamin selanjutnya berikatan pada reseptor $\beta$-adrenergik pada sel-sel imun. Dampaknya, terjadi penurunan kadar TNF- $\alpha$ (sitokin pro-inflamatorik) dan peningkatan IL-10 (sitokin anti-inflamatorik). Selain memengaruhi sel imun secara langsung, katekolamin (dopamin) mampu mendorong kondisi imunodepresi dengan cara penurunan respons (downregulation) ekspresi nuclear factor kappa-light-chain-enhancer of activated B cells (NF-kB), suatu faktor transkripsi yang berperan sebagai pengatur utama respons inflamasi. Nuclear factor kappa-light-chainenhancer of activated $B$ cells mengatur ekspresi berbagai mediator proinflamatorik, termasuk molekul adhesi, kemokin, sitokin, enzim, dan faktor angiogenik. Ketika transduksi sinyal maupun aktivasi $\mathrm{NF}-\kappa \mathrm{B}$ terhambat, maka respons neuroinflamasi pun ikut terpengaruh. ${ }^{28}$ 
Mekanisme kontrol inflamasi lainnya dijalankan oleh nervus vagus sebagai bagian dari sistem saraf parasimpatis. Melalui reseptor nikotinik, nervus vagus eferen dapat mensekresikan noradrenalin dan mengaktifkan jaras kolinergik yang bersifat antiinflamasi. ${ }^{29}$ Melalui mekanisme ini, timbul suatu proteksi neuron dari stres oksidatif sehingga mempercepat proses pemulihan. ${ }^{30}$ Akibatnya, stimulasi pada reseptor nikotinik, misalnya yang ditemukan pada makrofagalveolar, dapatmenghambat produksi sitokin-sitokin proinflamatorik. ${ }^{31}$

Secara sederhana, aksis hipotalamuspituitari-adrenal (HPA) teraktivasi saat terjadi sekresi corticotropin-releasing hormone (CRH) dari hipotalamus sebagai respons stres. Berbagai sitokin proinflamatorik, seperti IL-6, TNF- $\alpha$, dan IL-1 $\beta$, turut menstimulasi sintesis CRH. Pada fase akut stroke, sitokin-sitokin ini diproduksi secara signifikan sehingga terjadi respons aksis HPA berupa sekresi glukortikoid dalam jumlah masif. ${ }^{32}$

Glukortikoid menyebabkan apoptosis limfosit, serta limfopenia pascastroke. Molekul ini bekerja pada sel $\mathrm{T}$, yaitu menyebabkan penurunan produksi IFN- $\gamma$ dan pemicu apoptosis, serta pada monosit, yaitu stimulasi sekresi IL-10. ${ }^{18}$ Secara klinis, menurut studi Marklund dkk, kadar kortisol yang tinggi maupun rendah di darah pascastroke, berhubungan signifikan dengan peningkatan angka mortalitas. ${ }^{33}$

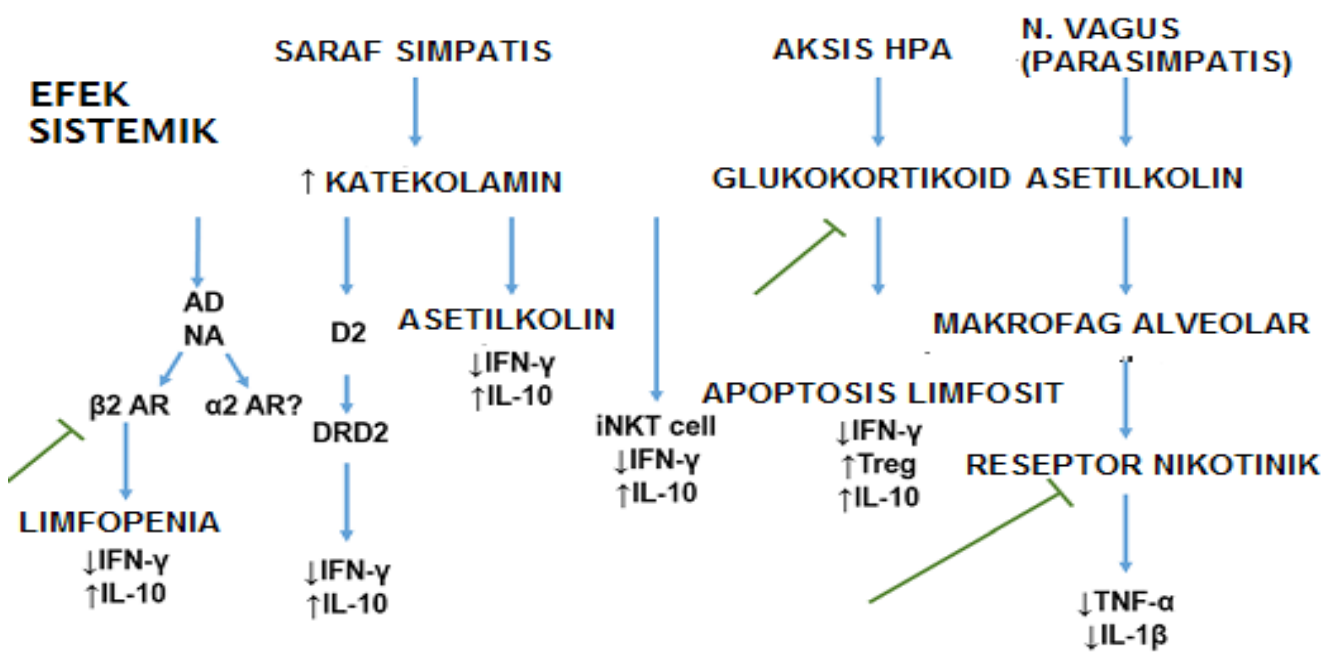

Gambar 2. Mekanisme Imunosupresi Pascastroke ${ }^{11}$

Overaktivasi saraf simpatis menyebebkan sekresi katekolamin, yang berikatan dengan reseptor $\beta$-adrenergik (AR $\beta 2$ ), reseptor dopamine (DRD2), asetilkolin, dan menyebabkan stimulasi invariant natural killer T-cell (iNKT) hepar. Selanjutnya, aksis HPA teraktivasi, sehingga terjadi sekresi glukokortikoid, dimana molekul ini akan menghambat produksi IFN- $\gamma$ dari sel T, merangsang apoptosis, serta mendorong sekresil IL-10 dari sel T regulator (Treg). N. vagus eferen dari saraf parasimpatis dapat memulai jalur antiinflamasi kolinergik melalui reseptor nikotinik yang berada di makrofag alveolar, sehingga produksi sitokin TNF- $\alpha$ dan IL-1 $\beta$ menurun. 
trial menunjukkan hasil berbeda. Menurut Hetze dkk, profilaksis antibiotik dapat menurunkan angka mortalitas pascastroke. ${ }^{35}$ Sementara itu, metaanalisis van de Beek dkk, menyimpulkan bahwa antibiotik hanya menurunkan risiko infeksi, namun tidak menurunkan angka mortalitas akibat stroke. ${ }^{36}$ Hasil serupa ditunjukkan oleh studi PANTHERIS, dimana pasien stroke yang diterapi dengan moxifloxacin memiliki risiko infeksi yang berkurang, namun angka penyintas (survival rate) maupun luaran neurologis tidak jauh berbeda dengan pemberian plasebo. ${ }^{37}$ Rekomendasi dari berbagai uji klinis terbaru ialah pemberian antibiotik sebagai profilaksis tidak direkomendasikan karena tidak menurunkan angka kejadian SAP maupun angka mortalitas, walau didapatkan penurunan risiko infeksi. ${ }^{38-39}$ Penggunaan antibiotik di tahap awal stroke dianggap tidak rasional dan mendorong terjadinya resistensi.

Selain antibiotik, tata laksana SAP juga memakai pendekatan berbasis proteksi saraf (neuroprotection) dan minimalisasi faktor risiko. ${ }^{40}$ Salah satunya adalah terapi antisimpatik/aksis HPA maupun antikolinergik. Penggunaan penyekat beta (contoh: propranolol) dan antagonis reseptor glukokortikoid (contoh: mifepristone) pada tikus dengan stroke dapat menurunkan volume infark secara signifikan, meningkatan penyintas (survival) jangka panjang, dan mendorong pemulihan. ${ }^{41}$ Dalam studi Sykora $\mathrm{dkk}$, penggunaan penyekat beta berhubungan dengan penurunan mortalitas oleh stroke dan insiden pneumonia nosokomial. ${ }^{42}$ Walau demikian, penelitian Westendorp dkk, memperlihatkan angka infeksi maupun pneumonia yang lebih tinggi pada pasien yang mendapat terapi penyekat beta sebelum mengalami stroke. ${ }^{43}$

Selain itu, statin, obat yang dikenal dalam terapi dislipidemia, mulai dipakai karena memiliki efek neuroprotektif dan meningkatkan pemulihan pascastroke. ${ }^{44}$ Studi metaanalisis Garcia-Bonilla dkk, menunjukkan bahwa simvastatin memiliki efek neuroprotektif tertinggi pada cedera otak. ${ }^{45}$ Beberapa terapi lain yang mulai dikembangkan untuk tata laksana stroke adalah terapi hipotermia dan terapi anti-inflamasi dan imunomodulasi. Berdasarkan studi $\mathrm{Gu} \mathrm{dkk}$, terapi hipotermia singkat $\left(28-30^{\circ} \mathrm{C}\right.$ dalam 1 jam) memperbaiki kondisi imunodepresi dengan cara memperkecil volume infark. ${ }^{46}$ Terapi ini masih dianggap kontroversial, mengingat beragam faktor yang memengaruhi status imun, seperti durasi hipotermia, tipe hipotermia (intermiten atau kontinyu), area (seluruh tubuh atau hanya area kepala). Di lingkup klinis, terapi ini masih jarang dipakai karena dianggap tidak praktis dan tidak efisien. Studi lanjutan skala besar diperlukan untuk mencari bukti klinis yang lebih kuat untuk mendukung penggunaan terapi ini. Sementara itu, beberapa golongan obat imunomodulator telah mencapai fase II uji klinis untuk terapi stroke, diantaranya antagonis reseptor IL-1 (anakinra), statin, fingolimod, citalopram, donepezil, siklosporin, dan natalizumab. ${ }^{47}$ Terapi berbasis sel punca (stem cell) juga banyak diteliti mengingat kelebihannya dalam efek neuroprotektif dan perbaikan neuron. ${ }^{48}$ Bone marrow mesenchymal stem cell (BMSC) berpengaruh pada regulasi sistem imun dan rekonstitusi imunitas. Berbagai uji klinis memperlihatkan terapi sel punca pascastroke terbukti aman, namun hasilnya masih kontroversial. ${ }^{49}$ Beberapa penyebabnya adalah karakteristik pasien yang beragam, waktu (timing) dimulainya terapi, dosis, tipe sel punca yang dipakai, dan modalitas terapi. Studi lebih lanjut diperlukan untuk mengetahui mekanisme di balik terapi sel punca sehingga dapat meningkatkan efektivitas terapi di masa datang.

Dapat disimpulkan, pendekatan komprehensif untuk pencegahan maupun tata laksana SAP masih menjadi tantangan, sehingga studi skala besar dan terpercaya dibutuhkan untuk memperjelas dampak imunodepresi pada SAP, sekaligus menentukan tata laksana yang tepat untuk SAP. ${ }^{40}$ Terapi immunomodulasi harus mendapat perhatian lebih mengingat potensi kerusakan lebih lanjut pada jaringan otak. Regimen terapi yang tepat mampu mencegah infeksi tanpa memperburuk kondisi iskemia.

\section{KESIMPULAN}

Walau berbagai studi telah membuktikan patofisiologi kondisi imunosupresi pascastroke dan pneumonia terkait stroke dari sudut pandang imunologi, studi lanjutan tetap diperlukan untuk 
menilai insiden dan luaran pneumonia terkait stroke secara pasti. Selanjutnya, penentuan regimen terapi profilaksis yang tepat diperlukan untuk mengurangi mortalitas dan morbiditas pada pasien pascastroke.

\section{DAFTAR PUSTAKA}

1. Smith CJ, Bray BD, Hoffman A, Meisel A, Heuschmann PU, Wolfe CDA, dkk. Can a novel clinical risk score improve pneumonia prediction in acute stroke care? A UK multicenter cohort study. J Am Heart Assoc. 2015;4(1):e001307.

2. Katzan IL, Cebul RD, Husak SH, Dawson NV,Baker DW. The effect of pneumonia on mortality among patients hospitalized for acute stroke. Neurology. 2003;60(4):620-5.

3. Wilson RD. Mortality and cost of pneumonia after stroke for different risk groups. J Stroke Cerebrovasc Dis. 2012;21(1):61-7.

4. Cohen DL, Roffe C, Beavan J, Blackett B, Fairfield CA, Hamdy S, dkk. Post-stroke dysphagia: a review and design considerations for future trials. Int $\mathrm{J}$ Stroke. 2016;11(4):399-411.

5. Prass K, Braun JS, Dirnagl U, Meisel C, Meisel A. Stroke propagates bacterial aspiration to pneumonia in a model of cerebral ischemia. Stroke. 2006;37(10):2607-12.

6. Hilker R, Poetter C, Findeisen N, Sobesky J, Jacobs A, Neveling M, dkk. Nosocomial pneumonia after acute stroke: implications for neurological intensive care medicine. Stroke. 2003;34(4):975-81.

7. Teramoto S. Novel preventive and therapuetic strategy for post-stroke pneumonia. Expert Rev Neurother. 2009;9(8):1187-200.

8. Horan TC, Andrus M, Dudeck MA. CDC/NHSN surveillance definition of health care associated infection and criteria for specific types of infections in the acute care setting. Am J Infect Control. 2008;36(5):309-32.

9. Hannawi Y, Hannawi B, Rao CPV, Suarez JI, Bershad EM. Stroke-associated pneumonia: major advances and obstacles. Cerebrovasc Dis. 2013;35(5):430-43.

10. Westendorp WF, Nederkoorn PJ, Vermeij JD, Dijkgraaf MG, Van-De-Beek D. Post-stroke infection: a systematic review and meta-analysis. BMC Neurol. 2011;11:110.

11. Samary CS, Pelosi P, Silva PL, Rocco PRM. Immunomodulation after ischemic stroke: potential mechanisms and implications for therapy. Critical Care. 2016;20(1):391.

12. Arai $T$, Yoshimi N, Fujiwara $H$, Sekizawa $K$. Serum substance $\mathrm{P}$ concentrations and silent aspiration in elderly patients with stroke. Neurology. 2003;61(11):1625- 6 .
13. Jia YX, Sekizawa K, Ohrui T, Nakayama K, Sasaki H. Dopamine D1 receptor antagonist inhibits swallowing reflex in guinea pigs. Am J Physiol. 1998;274(1):R76-80.

14. Nakagawa T, Ohrui T, Sekizawa K, Sasaki H. Sputum substance $\mathrm{P}$ in aspiration pneumonia. Lancet. 1995;345(8962):1447.

15. Yan L, Qing Y, Xingyi J, Hongbo Q. Etiologic diagnosis and clinical treatment of multiple drugresistant bacteria infection in elderly patients with strokeassociated pneumonia after neurosurgery. Cell Biochem Biophys. 2015;71(2):731-4.

16. Chamorro A, Meisel A, Planas AM, Urra X, van de Beek D, Veltkamp R. The immunology of acute stroke. Nat Rev Neurol. 2012;8(7):401-10.

17. Dirnagl U, Klehmet J, Braun JS, Harms H, Meisel C, Ziemssen T, dkk. Stroke-induced immunodepression: experimental evidence and clinical relevance. Stroke. 2007;38(2 Supl):770-3.

18. Prass K, Meisel C, Hoflich C, Braun J, Halle E, Wolf T, dkk. Stroke-induced immunodeficiency promotes spontaneous bacterial infections and is mediated by sympathetic activation reversal by poststroke $\mathrm{T}$ helper cell type 1-like immunostimulation. J Exp Med. 2003;198(5):725-36.

19. Kamel H, Iadecola C. Brain-immune interactions and ischemic stroke: clinical implications. Arch Neurol. 2012;69(5):576-81.

20. Meisel C, Schwab JM, Prass K, Meisel A, DIrnagl U. Central nervous system injury-induced immune deficiency syndrome. Nat Rev Neurosci. 2005;6(10):775-86.

21. Shi K, Wood K, Shi FD, Wang X, Liu Q. Strokeinduced immunosuppression and poststroke infection. Stroke Vasc Neurol. 2018;3(1):34-41.

22. Römer C, Engel O, Winek K, Hochmeister S, Zhang T, Royl G, dkk. Blocking stroke-induced immunodeficiency increases CNS antigen-specifi autoreactivity but does not worsen functional outcome after experimental stroke. J Neurosci. 2015;35(20):7777-94.

23. Haeusler KG, Schmidt WU, Fohring F, Meisel C, Helms T, Jungehulsing GJ, dkk. Cellular immunodepression preceding infectious complications after acute ischemic stroke in humans. Cerebrovasc Dis. 2008;25(1-2):50-8.

24. Vogelgesang A, Grunwald U, Langner S, Jack R, Broker BM, Kessler C, dkk. Analysis of lymphocyte subsets in patients with stroke and their influence on infection after stroke. Stroke. 2008;39(1):237-41.

25. Chamorro A, Horcajada JP, Obach V, Vargas M, Revilla M, Torres F, dkk. The Early Systemic Prophylaxis of Infection After Stroke study: a randomized clinical trial. Stroke. 2005;36(7):1495-500. 
26. Wang H, Yan FL, Cunningham M, Deng QW, Zuo L, Xing FL, dkk. Potential specific immunological indicators for stroke associated infection are partly modulated by sympathetic pathway activation. Oncotarget. 2016;7(32):52404-15.

27. Wong CH, Jenne CN, Lee WY, Leger C, Kubes P. Functional innervation of hepatic iNKT cells is immunosuppressive following stroke. Science. 2011;334(6052):101-5.

28. Shih RH, Wang CY, Yang CM. NF-kappaB signaling pathways in neurological inflammation: a mini review. Front Mol Neurosci. 2015;8:77.

29. Mravec B. The role of the vagus nerve in stroke. Auton Neurosci. 2010;158(1-2):8-12.

30. Cai PY, Bodhit A, Derequito R, Ansari S, Abukhalil $\mathrm{F}$, Thenkabail S, dkk. Vagus nerve stimulation in ischemic stroke: old wine in a new bottle. Front Neurol. 2014;5:107.

31. Rosas-Ballina M, Tracey KJ. Cholinergic control of inflammation. J Int Med. 2009;265(6):663-79.

32. Emsley HC, Smith CJ, Gavin CM, Georgiou RF, VailA, Barberan EM, dkk. An early and sustained peripheral inflammatory response in acute ischaemic stroke: relationships with infection and atherosclerosis. J Neuroimmunol. 2003;139(1-2):93-101.

33. Marklund N, Peltonen M, Nilsson TK, Olsson T. Low and high circulating cortisol levels predict mortality and cognitive dysfunction early after stroke. J Int Med. 2004;256(1):15-21.

34. Becker KJ, Buckwalter M. Stroke, inflammation and the immune response: dawn of a new era. Neurotherapeutics. 2016;13(4):659-60.

35. Hetze S, Engel O, Romer C, Mueller S, Dirnagl U, Meisel C, dkk. Superiority of preventive antibiotic treatment compared with standard treatment of poststroke pneumonia in experimental stroke: a bed to bench approach. J Cerebr Blood Flow Metabol. 2013;33(6):846-54.

36. Van-De-Beek D, Wijdicks EF, Vermeij FH, De-Haan RJ, Prins JM, Spanjaard L, dkk. Preventive antibiotics for infections in acute stroke: a systematic review and meta-analysis. Arch. Neurol. 2009;66(9):1076-81.

37. Harms H, Prass K, Meisel C, Klehmet J, Rogge W, Drenckhahn C, dkk. Preventive antibacterial therapy in acute ischemic stroke: a randomized controlled trial. PLoS One 3. 2008;3(5):e2158.

38. Kalra L, Irshad S, Hodsoll J, Simpson M, Gulliford M, Smithard D, dkk. Prophylactic antibiotics after acute stroke for reducing pneumonia in patients with dysphagia (STROKE-INF): a prospective, clusterrandomised, open-label, masked endpoint, controlled clinical trial. Lancet. 2015;386(10006):e1835-44.

39. Westendorp WF, Vermeij JD, Zock E, Hooijenga IJ, Kruyt ND, Bosboom HJLW, dkk. The Preventive Antibiotics in Stroke Study (PASS): a pragmatic randomized open-label masked endpoint clinical trial. Lancet. 2015;385:e1519-26

40. Liu DD, Chu SF, Chen C, Yang PF, Chen NH, $\mathrm{He} \mathrm{X}$. Research progress in stroke-induced immunodepression syndrome (SIDS) and strokeassociated pneumonia (SAP). Neurochemistry International. 2018;114:42-54.

41. Romer C, Engel O, Winek K, Hochmeister S, Zhang T, Royl G, dkk. Blocking stroke-induced immunodeficiency increases CNS antigen-specific autoreactivity but does not worsen functional outcome after experimental stroke. J Neurosci. 2015;35(20):e7777-94.

42. Sykora M, Siarnik P, Diedler J. Beta-blockers, pneumonia, and outcome after ischemic stroke: evidence from virtual international stroke trials archive. Stroke. 2015;46(2):1269-74.

43. Westendorp WF, Vermeij JD, Brouwer MC, Roos YB, Nederkoorn PJ, Van-De-Beek D, dkk. Prestroke use of beta-blockers does not lower poststroke infection rate: an exploratory analysis of the preventive antibiotics in stroke study. Cerebrovasc. Dis. 2016;42(5-6):e506-11.

44. Jin R, Zhu X, Liu L, Nanda A, Granger DN, Li G. Simvastatin attenuates stroke-induced splenic atrophy and lung susceptibility to spontaneous bacterial infection in mice. Stroke. 2013;44(4):e1135-43.

45. Garcia-Bonilla L, Campos M, Giralt D, Salat D, Chacon P, Hernandez-Guillamon M, dkk. Evidence for the efficacy of statins in animal stroke models: a meta-analysis. J Neurochem. 2012;122(2):e233-43.

46. Gu LJ, Xiong XX, Ito T, Lee J, Xu BH, Krams S, dkk. Moderate hypothermia inhibits brain inflammation and attenuates strokeinduced immunodepression in rats. CNS Neurosci Ther. 2014;20(1):e67-75.

47. Smith CJ, Denes A, Tyrrell PJ, Di Napoli M. Phase II anti-inflammatory and immune-modulating drugs for acute ischaemic stroke. Expet Opin Invest Drugs. 2015;24(5):e623-43.

48. Hao L, Zou Z, Tian H, Zhang Y, Zhou H, Liu L. Stem cell-based therapies for ischemic stroke. Biomed Res Int. 2014;2014:468748.

49. Chen L, Zhang G, Khan AA, Guo X, Gu Y. Clinical efficacy and meta-analysis of stem cell therapies for patients with brain ischemia. Stem Cells Int. 2016;2016:6129579. 